\title{
Cloning and expression of ethylene receptor ERS1 at various developmental and ripening stages of mango fruit
}

\author{
C.A. Contreras-Vergara ${ }^{1 *}$, N.A. Stephens-Camacho ${ }^{1 *}$, G. Yepiz-Plascencia ${ }^{1}$, \\ G.A. González-Aguilar ${ }^{1}$, A.A. Arvizu-Flores ${ }^{2}$, E. Sanchez-Sanchez ${ }^{3}$ \\ and M.A. Islas-Osuna ${ }^{1}$ \\ ${ }^{1}$ Centro de Investigación en Alimentación y Desarrollo, Hermosillo, \\ Sonora, México \\ 2Departamento de Ciencias Químico Biológicas, Universidad de Sonora, \\ Hermosillo, Sonora, México \\ ${ }^{3}$ Campo Experimental Valle del Mayo, \\ Instituto Nacional de Investigaciones Forestales, Agrícolas y Pecuarias, \\ Navojoa, Sonora, México \\ *These authors contributed equally to this study. \\ Corresponding author: M.A. Islas-Osuna \\ E-mail: islasosu@ciad.mx
}

Genet. Mol. Res. 11 (4): 4081-4092 (2012)

Received January 9, 2012

Accepted August 28, 2012

Published September 10, 2012

DOI http://dx.doi.org/10.4238/2012.September.10.6

\begin{abstract}
Ethylene induces characteristic ripening reactions in climacteric fruits through its binding to histidine-kinase (HK) receptors, activating the expression of ripening genes. Ethylene receptors have been found in Arabidopsis thaliana (Brassicaceae) and some fruits; number and expression patterns differ among species. In mango, only ethylene receptor ETR1 was known. We cloned ERS1 cDNA from mango, and evaluated the expression of Mi-ERS1 and Mi-ETR1 by qPCR in developmental and ripening stages of this fruit. The Mi-ERS1 coding sequence is $1890 \mathrm{bp}$ long and encodes 629 amino acids, similar to ERS1 from other fruits. Also, the amino acid sequence of ERS1 C-terminal HK domain shows the cognate fold after molecular modeling. Mi-ERS1 expression levels increased as mangoes ripened, showing the highest
\end{abstract}


levels at the climacteric stage, while Mi-ETR1 levels did not change during development and ripening. We conclude that the patterns of expression of Mi-ERS1 and Mi-ETR1 differ in mango fruit.

Key words: Ethylene receptor; Mangifera indica L.; Expression; Ripening; Molecular modeling

\section{INTRODUCTION}

Ethylene is involved in many physiological and developmental events in plants, playing an important role in ripening in all climacteric fruits, including mango (Mangifera indica L.) (Bleecker and Kende, 2000). Ethylene induces the characteristic reactions for fruit ripening, including the synthesis of enzymes involved in softening (cellular wall degradation) via depolymerization of matrix glycans (Brummell et al., 2004), the release of volatile compounds, and pigment production. These reactions occur in response to the binding of ethylene to receptors located in the membrane of the endoplasmic reticulum, which in turn initiates the multistep pathway involved in ethylene perception and signal transduction events (Giovannoni, 2001; Guo and Ecker, 2004).

Ethylene receptors (ETRs) are encoded by a small gene family of catalytic receptors found in bacteria and some eukaryotic systems known as 2-component regulators, and most of these are transmembrane sensor proteins (Marina et al., 2005). These systems, first described in bacteria, consist of 2 proteins - a sensor and a response regulator - that can modulate responses to a great variety of environmental stimuli (Grefen and Harter, 2004). The number of ETR isoforms varies from species to species, but all of the receptors share similar structures and contain an ethylene binding domain, a cGMP-specific phosphodiesterase, adenylyl cyclase and FhlA (GAF) domain of unknown function, and a histidine kinase (HK) domain. Five ETRs were initially identified in the model plant Arabidopsis thaliana [ETR1, ETR2, ethylene response sensor (ERS) 1, ERS2, and ethylene insensitive (EIN) 4] (Bleecker et al., 1998) and 6 in tomato (Lycopersicon esculentum) (Lashbrook et al., 1998; Tieman and Klee, 1999).

Based on ethylene binding domain sequence comparisons, various ETR isoforms in plants can be separated into 2 subfamilies: subfamily I members contain 3 transmembrane segments at their N-terminal hydrophobic domain (ETR1 and ERS1), and 4 of these segments occur in subfamily II (ETR2, ERS2, and EIN4) (Bleecker et al., 1998). The ETRs contain a receiver domain at the $\mathrm{C}$-terminus in addition to these domains. The 2 type of receptors function as homodimers linked by a disulfide bond at their N-terminals (Hall et al., 2000). In the absence of ethylene, the HK domain of the constitutive triple response 1 domain (CTR1), a negative regulator of the pathway, represses ethylene response; ethylene binding by the receptor induces a CTR1 conformational change, reducing its kinase activity and thereby activating the ethylene response pathway (Gao et al., 2003; Huang et al., 2003).

Despite the growing knowledge of the characterization of these receptors, little is known about the expression of ETR and ERS coding genes in fruits that are not model systems. Currently, 5 ETRs have been identified in apple (Tatsuki et al., 2007; Wiersma et al., 2007), 4 in pear (El-Sharkawy et al., 2003), 3 in peach (Rasori et al., 2002; Trainotti et al., 2005), 3 in persimmon (Pang et al., 2007), 2 in melon (Sato-Nara et al., 1999), and 1 in mango (Martínez et al., 2001). Expression studies of ETR genes have revealed a differential expression pattern related to the type of tissue, developmental stage, and exogenous application of ethylene. In A. thaliana, the 
expression of At-ETR 1 is ubiquitous and ethylene independent, whereas that of At-ERS1 is tissue specific, ethylene dependent, and developmentally regulated (Hua et al., 1998). In peach (Prunus persica), Pp-ETRI appears to be constitutively expressed and ethylene independent, whereas the Pp-ERS1 transcription rate dramatically increases in activated leaf and fruitlet abscission zones as well as in ripening fruit (Rasori et al., 2002). In melon fruit, ERS1 accumulates during enlargement on both the transcript and protein levels (Ma et al., 2006a).

In this study, the nucleotide sequence of ERSI complementary DNA (cDNA) was obtained and its expression was evaluated in mango fruit at various developmental and ripening stages. We also examined some structural features of ERS1 based on the molecular modeling of its HK domain, which is characteristic for this receptor type.

\section{MATERIAL AND METHODS}

\section{Plant material}

M. indica L. fruits from the cultivar 'Kent' were harvested by hand at the research station Valle del Mayo $\left(27^{\circ} 0437.96 \mathrm{~N}\right.$ and $\left.109^{\circ} 2705.56 \mathrm{~W}\right)$ of the National Institute of Forestry, Agricultural and Veterinary Research in Navojoa, Sonora. Fruits were picked based on days after flowering (DAF) at developmental stages S1 (106 DAF) and S2 (122 DAF) and at physiological maturity or S3 (189 DAF). To obtain samples of stage S4 (commercial maturity), fruits were ripened under laboratory conditions by storing them at $20^{\circ} \mathrm{C}$ with $65 \%$ humidity.

\section{Respiration}

$\mathrm{CO}_{2}$ production was measured using gas chromatography. The measurement was made with a gas chromatograph Varian Star 3400 (Varian, Walnut Creek, CA, USA) equipped with flame ionization detectors and thermal conductivity and a 2-m metal column filled with Hayesep N 800/100 (Varian) (Watada and Massie, 1981). Mango fruits selected and harvested in each developmental stage were measured 3 times. The fruits were placed in sealed plastic containers for $1 \mathrm{~h}$ at $20^{\circ} \mathrm{C}$, and $\mathrm{CO}_{2}$ headspace concentration was analyzed by withdrawing a $1-\mathrm{mL}$ sample from the container and injecting it into the gas chromatograph. A standard of 5\% was used, and $\mathrm{CO}_{2}$ concentration was obtained using the following formula:

$$
\mathrm{mL} \mathrm{CO}_{2} \cdot \mathrm{kg}^{-1} \cdot \mathrm{h}^{-1}=\frac{(\text { sample area) } \text { (standard concentration) (head space area) }}{\text { (incubation time) }(\text { standard area) }(\text { sample weight })}
$$

\section{RNA isolation and cDNA synthesis}

Total RNA was isolated and purified from mango seeds for cloning purposes and from mesocarp tissue for expression analysis using a Qiagen RNeasy Plant Mini Kit ${ }^{\mathbb{B}}$ (Qiagen, Mississauga, Ontario, Canada) and the supplied RLT extraction buffer according to manufacturer instructions. RNA quantity was estimated at $260 \mathrm{~nm}$ using a NanoDrop ND-1000 ultravioletvisible spectrophotometer (NanoDrop Technologies Inc., Wilmington, DE, USA). RNA integrity was detected via agarose gel electrophoresis. The cDNA synthesis from RNA obtained from both tissues was performed via reverse transcription of $1.0 \mu \mathrm{g}$ RNA using a Creator ${ }^{\mathrm{TM}}$ SMART $^{\mathrm{TM}}$ cDNA Library Construction Kit (Clontech Laboratories, Palo Alto, CA, USA). 


\section{Cloning of ERS1 cDNA}

Mi-ERS1 cDNA was obtained using degenerated primers ReEt Fw (5'-GAITGTGCI TTGTGGATGCC-3') and ReEt Rw (5'-ATIGCAGCATGIGAIAGAGC-3'). Reactions were performed on a Peltier thermal cycler (DNA Engine, BioRad, Hercules, CA, USA) using Platinum PCR Super Mix (Invitrogen) and $100 \mathrm{ng}$ cDNA as a template under the following conditions: $5 \mathrm{~min}$ at $94^{\circ} \mathrm{C}$, followed by 30 cycles of $45 \mathrm{~s}$ at $94^{\circ} \mathrm{C}, 90 \mathrm{~s}$ at $50^{\circ} \mathrm{C}, 1 \mathrm{~min}$ at $72^{\circ} \mathrm{C}$, and $5 \mathrm{~min}$ at $72^{\circ} \mathrm{C}$ as a final extension. The polymerase chain reaction (PCR) products were thoroughly sequenced at the University of Arizona Genetics Core (Tucson, AZ, USA) and analyzed using the Basic Local Alignment Search Tool algorithm (Altschul et al., 1990) against the GenBank database. Specific primers were designed to walk over the cDNA and were used to obtain the 5'- and 3'-ends in accordance with manufacturer instructions for a DNA Walking kit (SeeGene, USA). The following primers were used to walk over the 5'-end: Mi-ERS4, 5'-GAGACAGTTCTAAAGAGTAG-3'; Mi-ERS2, 5'-GCCACTTGCAGATTGAAC-3', and Mi-ERS1, 5'-GTGAAGATTGAATGGTCC-3'. The following primers were used for the 3'end: Mi-ERS5, 5'-GACTTGCCATTAGCAGAAGG-3'; Mi-ERS1F, 5'-CTTGAGTGTTGCGT TGTGGATG-3', and Mi-ERS3F, 5'-GCGCTGTAATGAACCATG-3'. Contiguous sequences were assembled using the DNA sequence assembly program CAP3 from non-ambiguous sequences of both strands to assemble the Mi-ERS1 cDNA sequence.

\section{Mi-ERS1 and Mi-ETR1 expression analysis}

Quantitative reverse transcription coupled with quantitative PCR (qRT-PCR) was carried out using the Full Velocity ${ }^{\mathrm{TM}} \mathrm{SYBR}^{\circledR}$ Green qRT-PCR Master Mix (Stratagene, La Jolla, CA, USA). Specific primers for Mi-ERS1 (sense, 5'-CTTTGATAAAGCCAATCGCA-3'; antisense, 5'-GTAAATTTCACAGCGTTGCC-3'), Mi-ETR1 (sense, 5'-AATATATGCCTGGCGA GGTG-3'; antisense, 5'-TGCACTATCTGAGGGAAGCA-3'), and mango glyceraldehyde 3-phosphate dehydrogenase gene $(G A P D H)$ (sense, 5'-GTGGCTGTTAACGATCCCTT-3'; antisense, 5'-GTGACTGGCTTCTCATCGAA-3') were designed to amplify products of $150 \mathrm{bp}$. Three replications were carried out for each sample in reactions with a final volume of $25 \mu \mathrm{L}$ containing $100 \mathrm{ng}$ total RNA, $75-125 \mathrm{nM}$ gene-specific primers, $0.0625 \mu \mathrm{L}$ Stratascript RT/RNase block (Stratagene), and Full Velocity ${ }^{\mathrm{TM}}$ SYBR $^{\circledR}$ Green qRT-PCR Master Mix. The PCR products were amplified in a SmartCycler (Cepheid, Sunnyvale, CA, USA) using the following conditions: $50^{\circ} \mathrm{C}$ for $30 \mathrm{~min}$ (cDNA synthesis), $95^{\circ} \mathrm{C}$ for 5 min, and 50 cycles of $95^{\circ} \mathrm{C}$ for $10 \mathrm{~s}$ and $60^{\circ} \mathrm{C}$ for $30 \mathrm{~s}$. To calculate the expression of MiERS1 and Mi-ETR1 receptors, we used the $2^{-\Delta \Delta C T}$ method (Livak and Schmittgen, 2001). Data were analyzed based on the $\mathrm{C}_{\mathrm{T}}$ value of each sample during PCR amplification, where $-\triangle \Delta C T$ was $-\left[\left(\mathrm{C}_{\mathrm{T}}\right.\right.$ target $\left.-\mathrm{C}_{\mathrm{T}} \mathrm{GAPDH}\right)-\left(\mathrm{C}_{\mathrm{T}} A v g\right.$ target- $\left.\left.\mathrm{C}_{\mathrm{T}} A v g \mathrm{GAPDH}\right)\right]$, and $A v g$ corresponded to the averaged $\mathrm{C}_{\mathrm{T}} \mathrm{S}$ from runs of developmental stage $\mathrm{S} 1$. The results are reported as relative mRNA steady-state levels of the target gene and normalized to GAPDH expression levels. Statistical analysis was carried out with one-way analysis of variance, and for post $h o c$ analysis, we used the Tukey test. Statistical significance was considered when the P value was 0.05 , and analyses were performed using the NCSS (2001) software (Kaysville, UT, USA). 


\section{Molecular modeling of ERS1}

The molecular structure of the cytoplasmic portion of Mi-ERS1 was predicted through homology modeling with the HK topology of bacteria (Marina et al., 2005; Casino et al., 2009). The theoretical structure was obtained with the Molecular Operating Environment software version 2010.10 (Chemical Computing Group, Montreal, Canada). A multiple sequence alignment was used to improve the homology model using the sequences of the ETR for other plants. The coordinates used for molecular model building were those for the HK of Thermotoga maritima bacteria from 2 different crystal structures deposited in the Protein Data Bank (codes 3DGE and $2 \mathrm{C} 2 \mathrm{~A}$ ). A total of 50 intermediate models were generated from the alignment for the cytoplasmic region of Mi-ETR under the CHARMM27 force field. The final model was further refined through an energy minimization scheme in Molecular Operating Environment starting from the best of the intermediate models according to the protein geometry utility of the software.

\section{RESULTS}

\section{$\mathrm{CO}_{2}$ production}

Mangos in 2 stages of development (S1 and S2) were selected based on 106 and 122 DAF, respectively; stage S3 was obtained at 189 DAF (physiological maturity), and the final stage (S4, commercial maturity) was obtained through storage at $20^{\circ} \mathrm{C}$ with a $60 \%$ relative humidity for 10 days. The respiratory rates determined with gas chromatography appear in Figure 1. The $\mathrm{CO}_{2}$ production trend is typical for climacteric fruits. The first stage corresponded to $\mathrm{S} 1$, and the respiratory rate yielded a $\mathrm{CO}_{2}$ concentration of $87 \mathrm{~mL} \cdot \mathrm{kg}^{-1} \cdot \mathrm{h}^{-1}$. At the $\mathrm{S} 2$ stage, metabolism slowed during development, and $\mathrm{CO}_{2}$ production diminished until respiration reached 25 $\mathrm{mL} \cdot \mathrm{kg}^{-1} \cdot \mathrm{h}^{-1}$. An increase in respiration with $\mathrm{CO}_{2}$ levels between 60 and $65 \mathrm{~mL} \cdot \mathrm{kg}^{-1} \cdot \mathrm{h}^{-1}$ occurred in the next 2 stages because the fruit returns to an accelerated metabolism, synthesizing enzymes for metabolic processes that result in the organoleptic characteristics of the mature fruit; these processes are reflected by changes in fruit color, texture, and aroma.

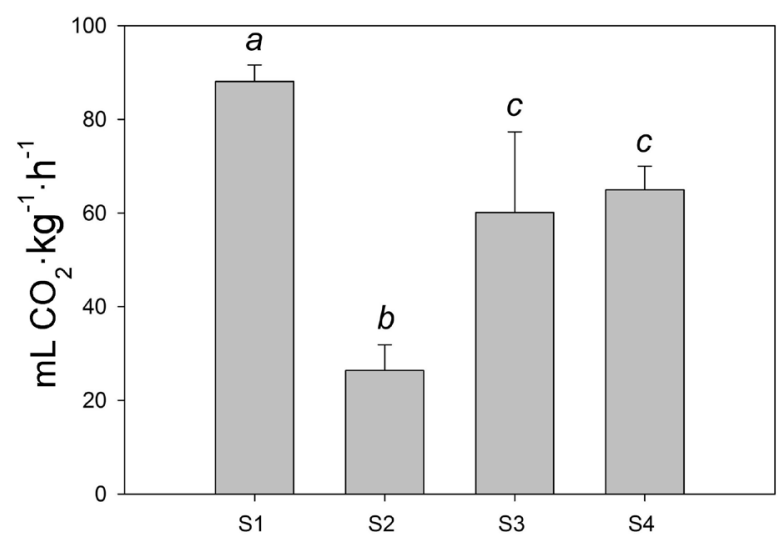

Figure 1. Levels of $\mathrm{CO}_{2}$ produced by mango fruits in two stages of development (S1 and S2) and two ripening stages (S3 and S4). Data are means of at least three determinations. Mean values in each bar followed by a different letter at each stage of development are significantly different $(\mathrm{P}<0.05)$. 


\section{cDNA and deduced amino acid sequence of Mi-ERS1}

The complete sequence of the Mi-ERS1 cDNA (GenBank JN851132) is 1908 bp with an 18-bp 5'-untranslated region and an 1890-bp open reading frame including the initial methionine and the stop codon (Figure 2). The 1890-bp open reading frame encodes a protein of 629 amino acid residues with a theoretical isoelectric point of 6.86 and a molecular weight of $70.3 \mathrm{kDa}$, which is similar to that of other ETRs from fruits. Multiple amino acid sequence alignment with other species showed that Mi-ERS1 is highly conserved between climacteric and non-climacteric fruits (Figure 3). The deduced protein was 78\% identical to ERS1 from a citrus hybrid cultivar (ADB25216.1) and 76\% to ERS1 from passion fruit (Passiflora edulis, BAA37137.1), plum (Prunus domestica, CAI64504.1), and peach (P. persica, AAM89517.1). The Mi-ERS1 sequence contained the 3 characteristic domains for ETR subfamily I members: an ethylene binding domain containing 3 membrane-spanning motifs (residues 25-119), a GAF domain (159-307), and an HK domain (344-577).

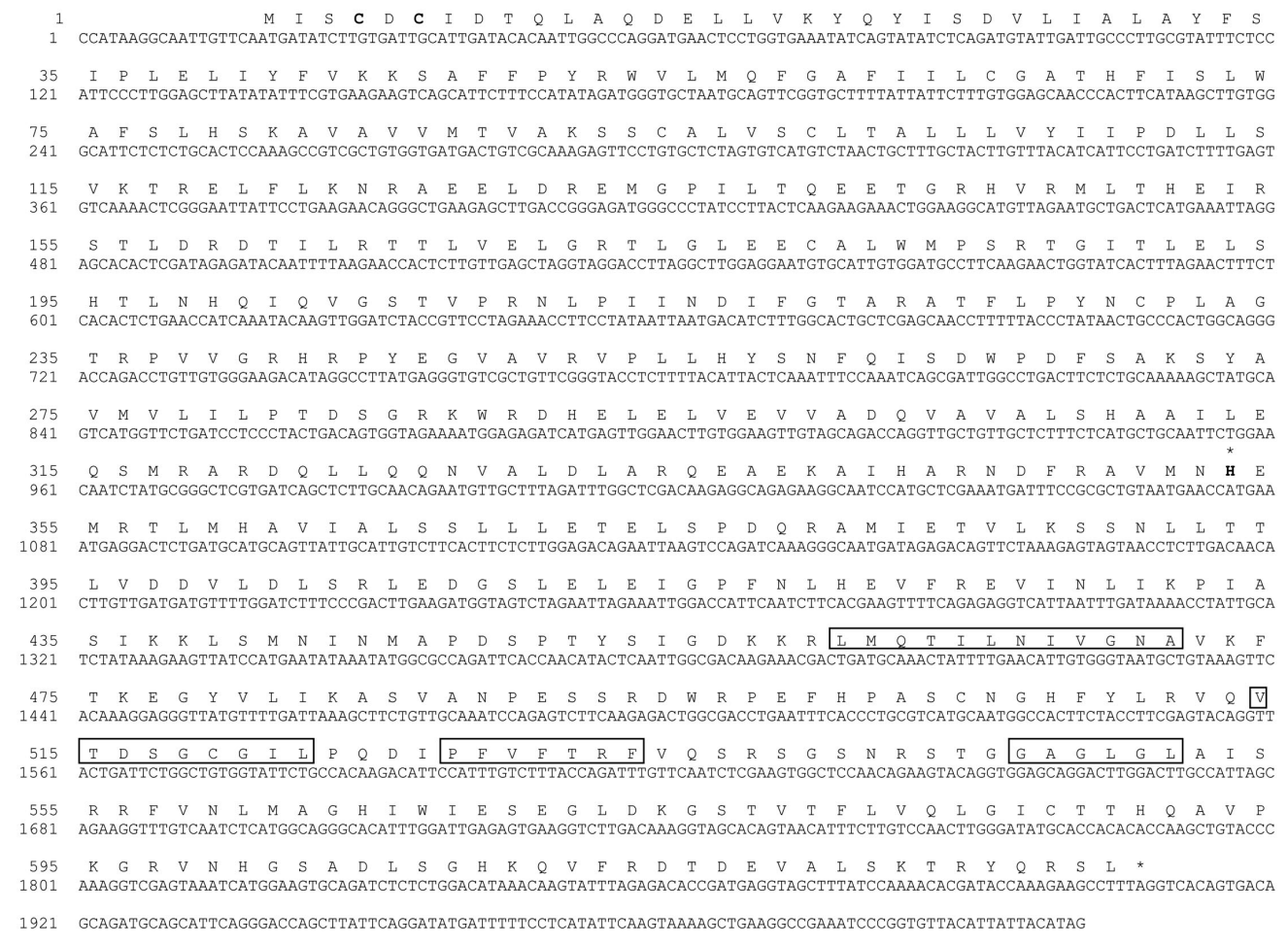

Figure 2. Nucleotide and deduced amino acid sequence for mango ERS1. The stop codon is labeled with an asterisk. In boldface, Cys 4 and Cys 6 involved in dimerization and phosphorylation site His 353. Subdomains N, $\mathrm{G}, \mathrm{F}$, and $\mathrm{G}$ present in the histidine kinase domain of subfamily I ethylene receptors are in boxes. 


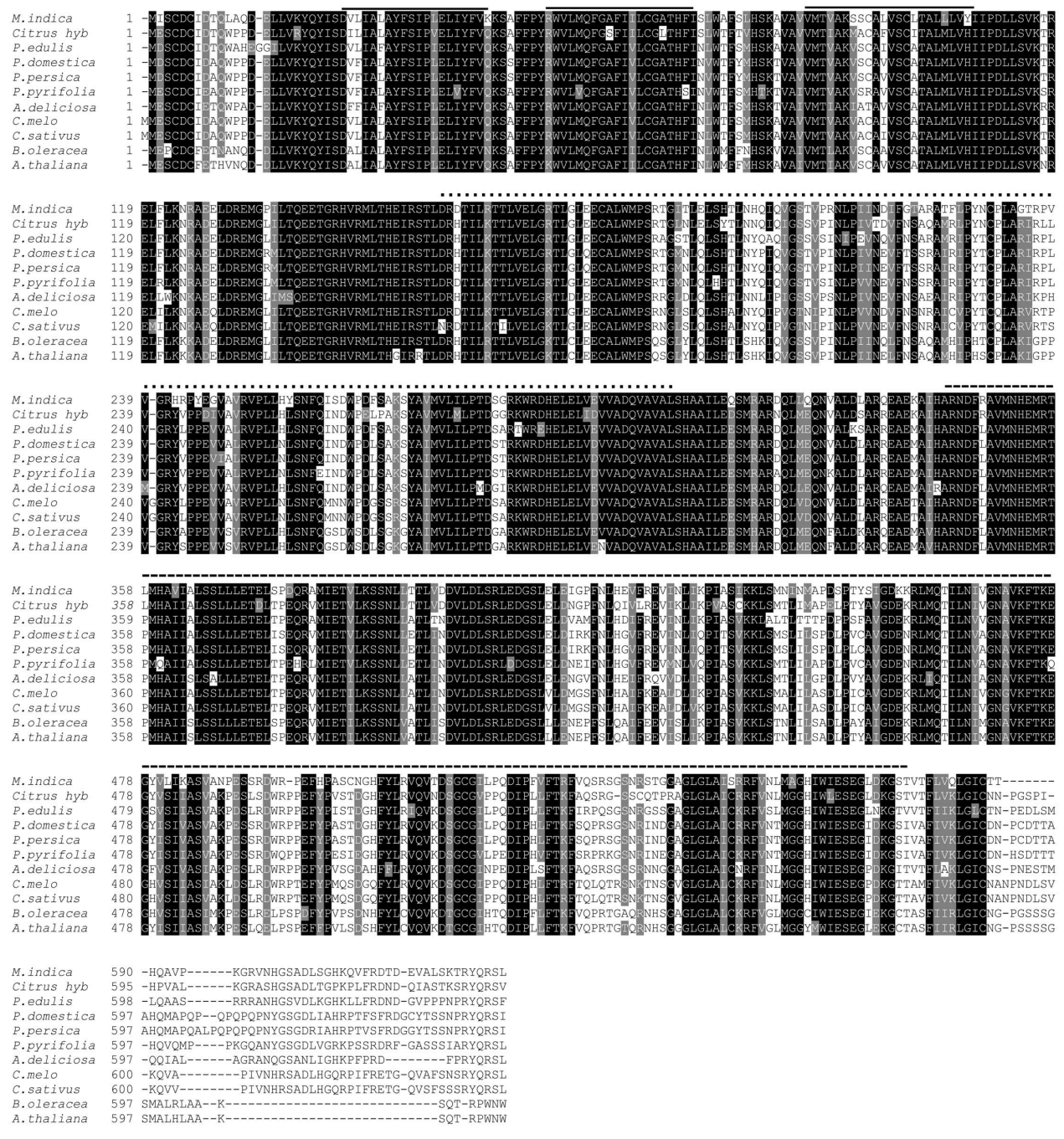

Figure 3. Multiple amino acid sequence alignment of Mangifera indica L. ERS1 with other plant ERS. Citrus hybrid cultivar (ADB25216.1), passion fruit (Passiflora edulis BAA37137.1), Damson plum (Prunus domestica subsp insititia, CAI64504.1), peach (Prunus persica, AAM89517.1), Nashi pear (Pyrus pyrifolia, ABV04082.1), kiwi (Actinidia deliciosa, ABY28263.1), Cantaloup melon (Cucumis melo var. Cantalupensis, BAB13735.1), cucumber (Cucumis sativus, BAA85818.1), cabbage (Brassica oleracea, AAC31157.1), and Arabidopsis thaliana (AAB86454.1). The three $\alpha$-helix domains spanning the membrane are marked with a continuous line, the GAF domain is marked with a pointed line and the histidine kinase domain in dashed line. Identical amino acids are indicated in black regions, and conservative replacements in gray regions. 


\section{Expression of Mi-ERS1 and Mi-ETR1 during development and ripening}

To explore Mi-ERS1 and Mi-ETR1 expression during fruit development, we analyzed their transcripts with quantitative PCR (Figure 4). Mi-ERS1 mRNA levels remained constant during stages $\mathrm{S} 1$ to $\mathrm{S} 3$, then showed an 8-fold increase in expression at stage $\mathrm{S} 4$ (mature mango). The Mi-ETR1 mRNA levels did not change significantly in fruits during the S1 developmental stage or throughout the processes that followed until the commercial ripening stage (S4).

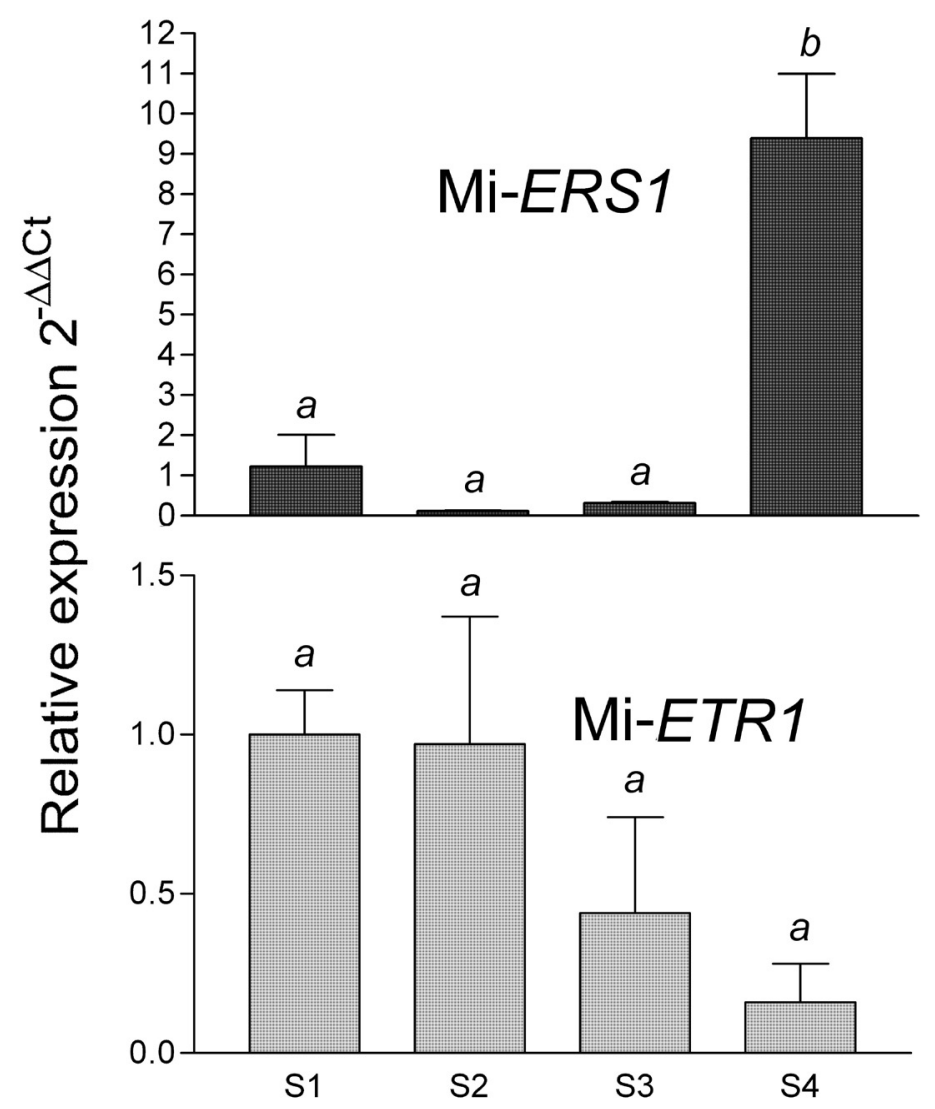

Figure 4. Relative expression of Mi-ERS1 and Mi-ETR1 at developmental stages $\mathrm{S} 1, \mathrm{~S} 2$, and ripening fruits at $\mathrm{S} 3$ and S4 stages. Different letters show statistical difference $(\mathrm{P}<0.05)$ between stages of development. S1 $=106$ days after flowering, S2 = 122 days after flowering, S3 = physiological maturity, and S4 = commercial maturity. Data was normalized with the GAPDH constitutive gene.

\section{Molecular modeling of ERS1 cytoplasmic domain}

The deduced protein sequence of Mi-ERS1 displayed the N-terminal sensor domain and the C-terminal HK domain, connected through the GAF domain (Ma et al., 2006b). A multiple sequence alignment of ERS1 to other homologs from plants showed a high degree of con- 
servation for the 3 domains (Figure 5). The N-terminus showed a high potential for forming transmembrane $\alpha$-helices, which span the membrane of the endoplasmic reticulum, as seen in a protease protection assay (Ma et al., 2006b). The C-terminal HK portion of ERS1 (residues 344-577) was modeled, adopting the topology for this receptor type, which is a dimer with an interface of $4 \alpha$-helices. The HK portion of ERS1 had 31\% sequence identity with the bacterial HK that was used as a template for homology modeling.

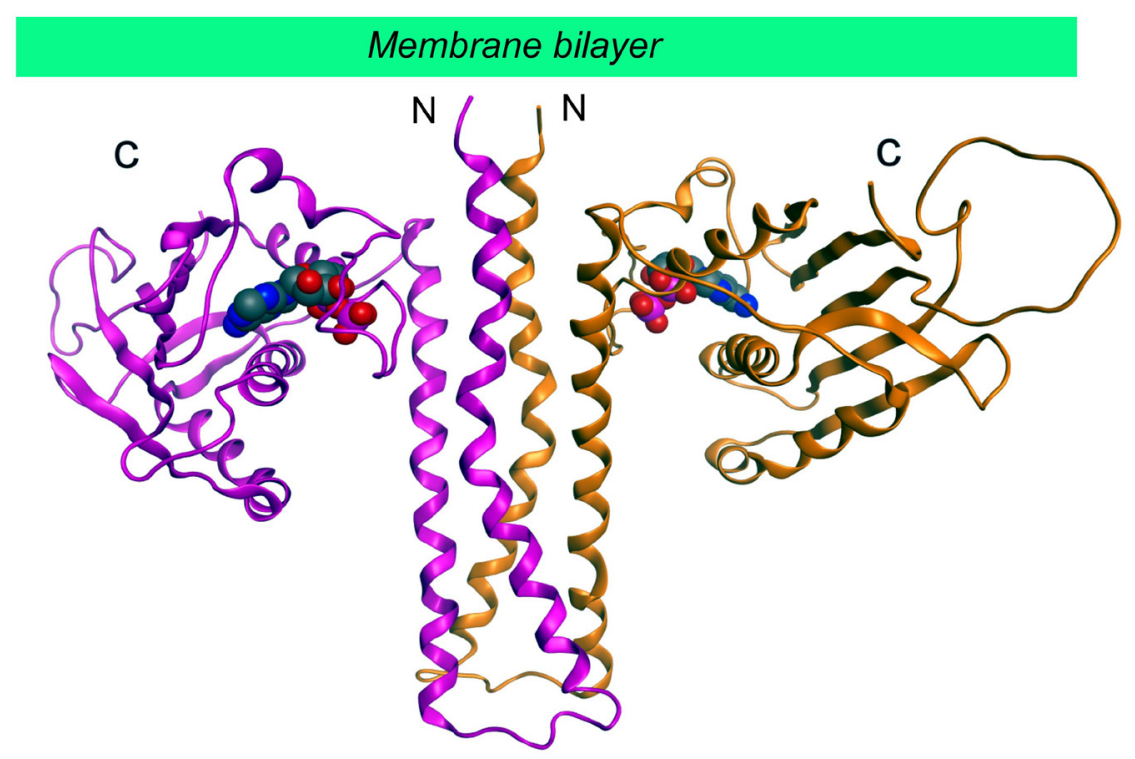

Figure 5. Molecular modeling of mango ERS1 cytoplasmic domain. Ribbon representation of ERS1 dimer based on homology modeling, including ADP molecule shown in sphere representation. The $\mathrm{N}$ - and $\mathrm{C}$-terminal positions are labeled in each subunit, A (pink) and B (golden). The membrane would be located on the top of N-terminal residues.

\section{DISCUSSION}

Harvested fruits are classified as climacteric or non-climacteric based on their respiratory pattern and ethylene biosynthesis during ripening. Climacteric fruits harvested at full maturity can be ripened out of the parent plant. The respiration rate and ethylene formation, although minimal at maturity, rise dramatically to a climacteric peak at the onset of ripening, after which they decline (Prasanna et al., 2007).

Respiration rate, measured as $\mathrm{CO}_{2}$ production, is a strong indicator of maturity in climacteric fruit. Akamine and Goo (1973) have reported 1-day difference between $\mathrm{CO}_{2}$ level and ethylene production peaks in the mango 'Kensington Pride' at ripening. Studies carried out by Lalel et al. (2003) to study the respiration process in mango fruit development have shown a low $\mathrm{CO}_{2}$ level in early developmental stages and later an increment of $\mathrm{CO}_{2}$ production at ripening. This result is in accordance with our data, which revealed a decrease in $\mathrm{CO}_{2}$ level at the S2 stage followed by a 2.4-fold increase at the S3 and a 2.6-fold increase at the S4 stages compared with that at S2.

Ethylene in minute amounts can trigger many cellular metabolic events, including rip- 
ening initiation and senescence, particularly in climacteric fruit. Ethylene is synthesized autocatalytically at levels as low as $0.0016 \mathrm{nM}$ in the 'Kent' mango (Kader, 2002), triggering the ETR response leading to the ripening process. The expression of Mi-ERS1 and Mi-ETR1 was evaluated in this study using qRT-PCR of Mi-ERS1 and Mi-ETR1. During mango development, Mi-ERS1 transcripts remained unchanged and dramatically increased at the commercial ripening stage (S4) as a primary response to ethylene. Rasori et al. (2002) have reported that Pp-ERS genes are upregulated with auto-catalytically synthesized ethylene.

In contrast, Mi-ETR1 expression levels were similar during the 4 stages of mango fruit development, whereas Mi-ERS1 levels were higher than those of Mi-ETRI and increased during ripening. This expression behavior for ETR1 has been reported for other climacteric fruits, such as the passion fruit (Mita et al., 1998), peach (Bassett et al., 2002; Rasori et al., 2002), and kiwi (Yin et al., 2008), in which ETR1 expression is constant throughout the various developmental stages. As shown in this study (Figure 4), the expression of ETR1 in mango is constitutive during fruit development and ripening, unlike that of ERS1. This difference can be explained by the important structural differences between ERS1 and ETR1 proteins already known in the ETRs of other fruits. Both proteins, as ETR subfamily I members, have an overall similar sequence and share all the residues known to be essential for ethylene binding, although ERS1 lacks the response regulator domain found in ETR1 (Bleecker, 1999).

The ERS1 deduced amino acid sequence had $66 \%$ similarity to a reported Mi-ETR1 (Martínez et al., 2001) in accordance with the 63\% similarity reported between Pp-ETRs (Rasori et al., 2002). The low identity between Mi-ETR1 and Mi-ERS1 is mainly due to the lack of the response regulator domain in the latter. The response regulator domain is involved in phosphate transfer within the signaling pathways. Moreover, the ethylene response is regulated by its interaction with the CTR1 protein (Yoo et al., 2009). Huang et al. (2003) have reported an analysis of loss of CTR1 function in A. thaliana, in which the interaction of the N-terminal domain of CTR1 with ETR1 is required for the negative regulation of ethylene signaling. Thus, the authors have suggested that CTR1 kinase activity is directly activated by ETR1 in the absence of ethylene, and that the active CTR1 phosphorylates the downstream targets, turning off the ethylene response pathway.

Although ETR1 and ERS1 have important structural differences that may lead to quantitative differences in signaling, they share similar biochemical properties for ethylene sensing and phosphorylating activity in the HK domain. A highly conserved HK motif is shared by the deduced protein of Mi-ERS1 and a previously reported Mi-ETR1 protein (Martínez et al., 2001). This HK domain adopted the topology for the 2-component system for signal transduction in prokaryotes, fungi, and plants. This domain contains an HATPase-like region that is critical in phosphorylation and ATP binding. Until now, no ERS protein structure has been reported, and only 2 crystal structures exist for the HK domain from a single bacteria with homology to HK domains from plants (Marina et al., 2005). These crystallographic structures were used to obtain the HK cytoplasmic domain structure of Mi-ERS1. The HK domain is characterized by the presence of His (autophosphorylation site), Asn, Gly, Phe, and Gly (NGFG) residues, as reported for subfamily I receptors of $A$. thaliana (Hall et al., 2007) and L. esculentum (Klee and Tieman, 2002), and they are also present in Mi-ERS1.

Furthermore, Mi-ERS1 has the N-terminal hydrophobic domain containing 3 transmembrane regions capable of forming $\alpha$-helices, which is characteristic for members of subfamily I. The N-terminal domain is located in the endoplasmic reticulum lumen, at which ethylene is sensed, and it forms homodimeric links via a disulfide bond between Cys5 and 
Cys7 residues in Cucumis melo ERS1 (Ma et al., 2006a). These residues are present in the Mi-ERS1 deduced polypeptide, corresponding to Cys4 and Cys6. Although ETRs function as homodimers, the GAF domain has recently been reported to be capable of mediating heteromeric receptor interactions (Gao et al., 2008) as well as cyclic guanosine monophosphate binding and light regulation functions in some proteins.

A number of ETR subfamily I- and II-associated genes have been identified in fruits. The biochemical functions and interactions of those genes are still being studied because of the signaling and response complexity in the ripening process. An overlapping expression in plant tissues is exhibited by the ethylene response system receptors, but it may maintain distinct functional identity, responding differentially to developmental challenges that may vary among species. More detailed molecular information is required to reach a more comprehensive understanding of the ethylene hormone signaling pathway in climacteric fruits and determine how the expression of these genes may coordinate ethylene perception in fruits during the development process.

Mi-ERS1 was differentially expressed during mango fruit ripening, whereas Mi-ETR1 levels remained largely unchanged. Future experiments should aim to clone the components of the ethylene signal transduction pathway in mango fruits and to evaluate the expression of these genes. An understanding of these processes could be helpful in the development of transgenic mango plants with retarded ripening.

\section{ACKNOWLEDGMENTS}

We thank Mexico's National Research Council for Science and Technology for a masters degree scholarship to N.A. Stephens-Camacho and for a grant to M.A. Islas-Osuna (\#60950). We also thank Monica G. Resendiz Sandoval, Emmanuel Aispuro-Hernández, and Marisol Ochoa-Villarreal for technical support, and Dr. Rogerio Sotelo-Mundo for a critical reading of the manuscript.

\section{REFERENCES}

Akamine E and Goo T (1973). Respiration and Ethylene production during ontogeny of fruit. J. Am. Soc. Hort. Sci. 98 : 381-383.

Altschul SF, Gish W, Miller W, Myers EW, et al. (1990). Basic local alignment search tool. J. Mol. Biol. 215: 403-410.

Bassett CL, Artlip TS and Callahan AM (2002). Characterization of the peach homologue of the ethylene receptor, PpETR1, reveals some unusual features regarding transcript processing. Planta 215: 679-688.

Bleecker AB (1999). Ethylene perception and signaling: an evolutionary perspective. Trends Plant Sci. 4: 269-274.

Bleecker AB and Kende H (2000). Ethylene: a gaseous signal molecule in plants. Annu. Rev. Cell Dev. Biol. 16: 1-18.

Bleecker AB, Esch JJ, Hall AE, Rodriguez FI, et al. (1998). The ethylene-receptor family from Arabidopsis: structure and function. Philos. Trans. R. Soc. Lond. B Biol. Sci. 353: 1405-1412.

Brummell DA, Dal Cin V, Crisosto CH and Labavitch JM (2004). Cell wall metabolism during maturation, ripening and senescence of peach fruit. J. Exp. Bot. 55: 2029-2039.

Casino P, Rubio V and Marina A (2009). Structural insight into partner specificity and phosphoryl transfer in twocomponent signal transduction. Cell 139: 325-336.

El-Sharkawy I, Jones B, Li ZG, Lelievre JM, et al. (2003). Isolation and characterization of four ethylene perception elements and their expression during ripening in pears (Pyrus communis L.) with/without cold requirement. J. Exp. Bot. 54: 1615-1625.

Gao Z, Chen YF, Randlett MD, Zhao XC, et al. (2003). Localization of the Raf-like kinase CTR1 to the endoplasmic reticulum of Arabidopsis through participation in ethylene receptor signaling complexes. J. Biol. Chem. 278: 34725-34732.

Gao Z, Wen CK, Binder BM, Chen YF, et al. (2008). Heteromeric interactions among ethylene receptors mediate signaling in Arabidopsis. J. Biol. Chem. 283: 23801-23810. 
Giovannoni J (2001). Molecular biology of fruit maturation and ripening. Annu. Rev. Plant Physiol. Plant Mol. Biol. 52: $725-749$.

Grefen C and Harter K (2004). Plant two-component systems: principles, functions, complexity and cross talk. Planta 219: 733-742.

Guo H and Ecker JR (2004). The ethylene signaling pathway: new insights. Curr. Opin. Plant Biol. 7: 40-49.

Hall AE, Findell JL, Schaller GE, Sisler EC, et al. (2000). Ethylene perception by the ERS1 protein in Arabidopsis. Plant Physiol. 123: 1449-1458.

Hall BP, Shakeel SN and Schaller GE (2007). Ethylene receptors: ethylene perception and signal transduction. J. Plant Growth Regul. 26: 118-130.

Hua J, Sakai H, Nourizadeh S, Chen QG, et al. (1998). EIN4 and ERS2 are members of the putative ethylene receptor gene family in Arabidopsis. Plant Cell 10: 1321-1332.

Huang Y, Li H, Hutchison CE, Laskey J, et al. (2003). Biochemical and functional analysis of CTR1, a protein kinase that negatively regulates ethylene signaling in Arabidopsis. Plant J. 33: 221-233.

Kader AA (2002). Postharvest Technology of Horticultural Crops. 3rd edn. University of California, Oakland.

Klee H and Tieman D (2002). The tomato ethylene receptor gene family: Form and function. Physiol. Plant 115: 336-341.

Lalel HJD, Singh Z and Tan SC (2003). The role of ethylene in mango fruit aroma volatiles biosynthesis. J. Hortic. Sci. Biotechnol. 78: 485-496.

Lashbrook CC, Tieman DM and Klee HJ (1998). Differential regulation of the tomato ETR gene family throughout plant development. Plant J. 15: 243-252.

Livak KJ and Schmittgen TD (2001). Analysis of relative gene expression data using real-time quantitative PCR and the $2^{-\Delta \Delta C}$ Method. Methods 25: 402-408.

Ma B, Cui ML, Sun HJ, Takada K, et al. (2006a). Subcellular localization and membrane topology of the melon ethylene receptor CmERS1. Plant Physiol. 141: 587-597.

Ma N, Tan H, Liu X, Xue J, et al. (2006b). Transcriptional regulation of ethylene receptor and CTR genes involved in ethylene-induced flower opening in cut rose (Rosa hybrida) cv. Samantha. J. Exp. Bot. 57: 2763-2773.

Marina A, Waldburger CD and Hendrickson WA (2005). Structure of the entire cytoplasmic portion of a sensor histidinekinase protein. EMBO J. 24: 4247-4259.

Martínez PG, Gómez RL and Gómez-Lim MA (2001). Identification of an ETR-1 homologue from mango fruit expressing during fruit ripening and wounding. J. Plant Physiol. 158: 101-108.

Mita S, Kawamura S, Yamawaki K, Nakamura K, et al. (1998). Differential expression of genes involved in the biosynthesis and perception of ethylene during ripening of passion fruit (Passiflora edulis Sims). Plant Cell Physiol. 39: 1209-1217.

Pang JH, Ma B, Sun H-J, Ortiz GI, et al. (2007). Identification and characterization of ethylene receptor homologs expressed during fruit development and ripening in persimmon (Diospyrus kaki Thumb.). Postharvest Biol. Tech. 44: 195-203.

Prasanna V, Prabha TN and Tharanathan RN (2007). Fruit ripening phenomena-an overview. Crit. Rev. Food Sci. Nutr. 47: 1-19.

Rasori A, Ruperti B, Bonghi C, Tonutti P, et al. (2002). Characterization of two putative ethylene receptor genes expressed during peach fruit development and abscission. J. Exp. Bot. 53: 2333-2339.

Sato-Nara K, Yuhashi KI, Higashi K, Hosoya K, et al. (1999). Stage- and tissue-specific expression of ethylene receptor homolog genes during fruit development in muskmelon. Plant Physiol. 120: 321-330.

Tatsuki M, Endo A and Ohkawa H (2007). Influence of time from harvest to 1-MCP treatment on apple fruit quality and expression of genes for ethylene biosynthesis and ethylene receptors. Postharvest Biol. Technol. 43: 28-35.

Tieman DM and Klee HJ (1999). Differential expression of two novel members of the tomato ethylene-receptor family. Plant Physiol. 120: 165-172.

Trainotti L, Pavanello A and Casadoro G (2005). Different ethylene receptors show an increased expression during the ripening of strawberries: does such an increment imply a role for ethylene in the ripening of these non-climacteric fruits? J. Exp. Bot. 56: 2037-2046.

Watada $\mathrm{H}$ and Massie D (1981). A compact automatic system for measuring CO2 and C2H4 evolution by harvest horticultural crops. HortScience 19: 39-41.

Wiersma PA, Zhang H, Lu C, Quail A, et al. (2007). Survey of the expression of genes for ethylene synthesis and perception during maturation and ripening "Sunrise" and "Golden Delicious" apple fruit. Postharvest Biol. Technol. 44: 204-211.

Yin XR, Chen KS, Allan AC, Wu RM, et al. (2008). Ethylene-induced modulation of genes associated with the ethylene signalling pathway in ripening kiwifruit. J. Exp. Bot. 59: 2097-2108.

Yoo SD, Cho Y and Sheen J (2009). Emerging connections in the ethylene signaling network. Trends Plant Sci. 14: 270-279. 